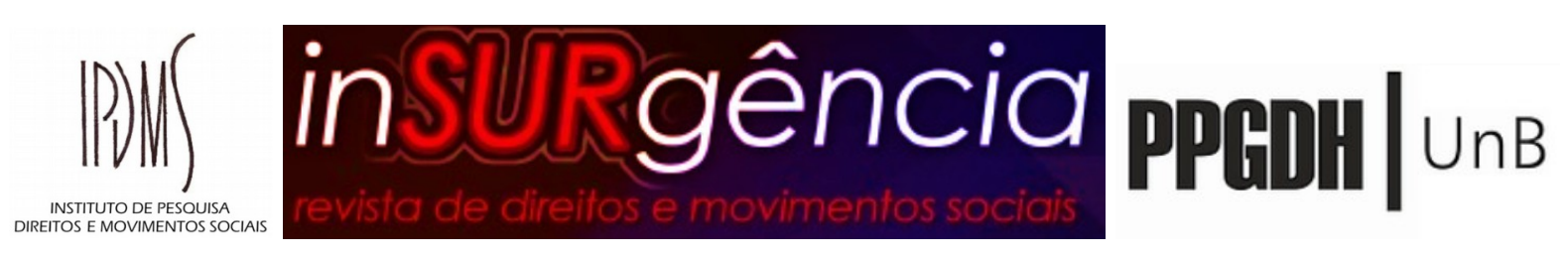

\title{
Contradições do Sistema Normativo Urbano-Ambiental e as Práticas Insurgentes de Produção do Lugar em São José do Norte, RS
}

Contradicciones del Sistema normativo urbano ambiental y las prácticas insurgentes de Producción de Lugar en São José do Norte (RS), Brasil

\author{
Rita de Cássia Gnutzmann Veiga ${ }^{1}$ \\ Marcelo Eibs Cafrune ${ }^{2}$
}

\begin{tabular}{|l|l}
\hline$(\boldsymbol{c c}) \mathbf{E Y}$ \\
EY
\end{tabular}

Resumo: O artigo discute a relação entre a produção dos assentamentos informais em São José do Norte (RS) e as sobreposições e ambiguidades normativas oriundas, em especial, do Direito Urbanístico e do Direito Ambiental. Como estudo de caso, foram analisados inquéritos civis que tramitam na Promotoria de Justiça do Estado do Rio Grande do Sul em São José do Norte, tendo por objeto a investigação de assentamentos irregulares formados, em geral, por população de baixa renda. A análise permitiu identificar que há: ausência de produção de loteamentos regulares; judicialização de conflitos urbano-ambientais; dificuldades práticas do Ministério Público e da Prefeitura Municipal na identificação das normas jurídicas aplicáveis. Tais elementos retratam um ordenamento jurídico urbano-ambiental descolado da realidade de uma cidade brasileira de pequeno porte.

Palavras-chave: Assentamentos informais; direito à moradia; estudo de caso; Direito Urbanístico; Direito Ambiental.

Resumen: El artículo relaciona la producción de asentamientos urbanos informales en la ciudad de São José do Norte (Rio Grande do Sul, Brasil) con las ambigüedades de las leyes urbanas y ambientales. Como estudio de caso, fueron analizados procedimientos de investigación civil del Ministerio Público que tratan de los asentamientos informales en los

1 Professora Doutora na Escola de Engenharia da Universidade Federal do Rio Grande - Furg. Arquiteta e Urbanista. Bacharela em Direito. Coordenadora do Grupo de Pesquisa Produção do Lugar e Responsabilidade Socioambiental. Email: ritaveiga@furg.br. ORCID: https://orcid.org/0000-0002-7032-5834.

2 Professor Doutor na Faculdade de Direito da Universidade Federal do Rio Grande - Furg. Advogado. Coordenador do Grupo de Pesquisa Direito e Sociedade. Email: marcelocafrune@gmail.com. ORCID: 


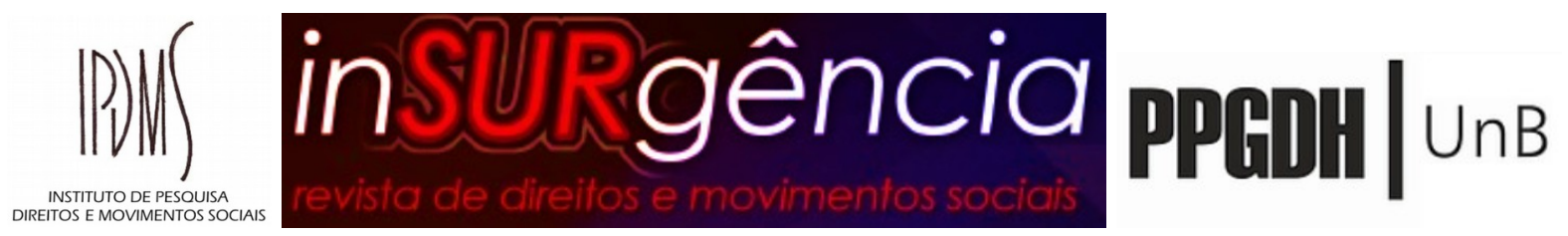

que viven, en general, la población de baja renta. El análisis permite decir que hay: escasez de producción de parcelas regulares; judicialización de conflictos urbano ambientales, dificultades prácticas del Ministerio Público y de la alcaldía para identificar las normas jurídicas aplicables. Los mencionados aspectos retratan un ordenamiento jurídico urbano ambiental apartado de la realidad de una pequeña ciudad brasileña.

Palabras-clave: Asentamientos informales; derecho a la vivienda; estudio de caso; Derecho Urbano; Derecho Ambiental.

\section{Introdução}

Historicamente, o Brasil enfrenta sérias dificuldades em conciliar as diversas normas de gestão do território à realidade da produção dos lugares. Entre elas, destaca-se a dificuldade enfrentada pelo Poder Público em lidar com assentamentos informais, característicos da urbanização brasileira, impedindo o acesso à moradia adequada para grande parcela da população. A irregularidade fundiária tem, entre suas causas, a urbanização acelerada, a grande concentração fundiária e a ausência de financiamento estrutural para a habitação em áreas previamente urbanizadas.

Para fazer frente a essa problemática, foi produzido, com protagonismo dos movimentos sociais urbanos, um amplo marco jurídico voltado à efetividade do direito à moradia e à realização do direito às cidades sustentáveis e democráticas, sintetizado pelo Estatuto da Cidade (Lei Federal n. 10.257/2001), que regulamentou o Capítulo da Política Urbana previsto na Constituição da República de 1988. Nesse período, diversas iniciativas buscaram promover a regularização fundiária. No âmbito legislativo, destacam-se o Capítulo III da Lei Federal n. 11.977/2009 e a Lei Federal n. 13.465/2017.

Há importante produção teórica sobre o tema no campo jurídico. Grande parte dos estudos destacam a importância dos instrumentos de regularização fundiária e, no geral, tratam da problemática a partir dos grandes centros urbanos. Contudo, parece ser necessário contribuir com essa discussão, voltando-se, de um lado, para a análise de processos de regularização fundiária, que permitam identificar dificuldades práticas, procedimentais e jurídicas e, de outro, para a realidade de cidades de pequeno porte, em que há limitações para a implementação de políticas públicas, tais como restrições orçamentárias, quadro técnico 


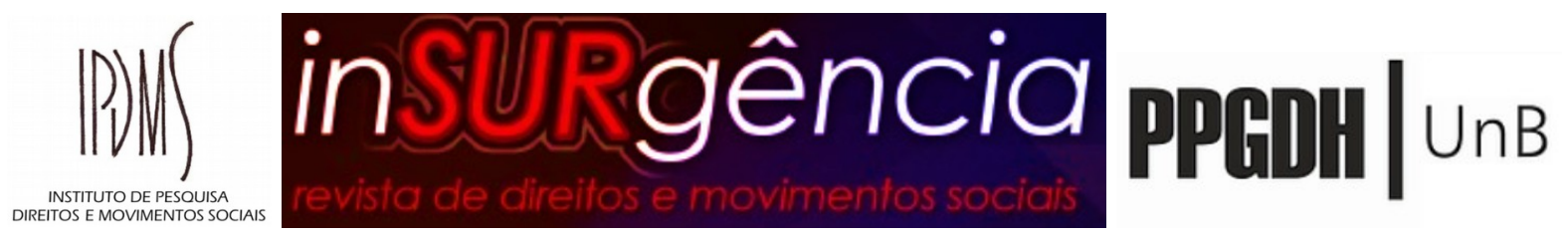

pequeno e desinteresse de empreendedores privados.

No Rio Grande do Sul, uma das cidades de pequeno porte que enfrenta dificuldades em conciliar as exigências legais para intervenção territorial é São José do Norte, objeto da presente análise. O recorte de pesquisa deu-se a partir de notícias da atuação do Ministério Público do Rio Grande do Sul (MP), que intensificou as ações de investigação acerca da produção de assentamentos informais no município de São José do Norte, com foco tanto nos loteadores quanto na municipalidade.

Para estudar o caso, além da utilização de fontes secundárias sobre a caracterização do município e de sua estrutura fundiária, foram analisados inquéritos civis que tramitam na Promotoria de Justiça do Município, iniciados em anos distintos e com base em motivações diversas, mas que possuem em comum a problemática da irregularidade. Nos casos analisados, destacaram-se a incidência, em tese, de violações à legislação urbanística e ambiental.

Neste artigo, objetiva-se i) apresentar a questão dos assentamentos urbanos irregulares; ii) descrever sucintamente a realidade urbana estudada e identificar, por meio da análise dos inquéritos civis, o enquadramento jurídico das práticas sociais de produção do lugar; e iii) discutir as contradições e os limites da legislação urbanística e ambiental aplicável.

\section{Urbanização, meio ambiente e irregularidade fundiária}

A gestão urbana e ambiental é uma atividade complexa, em que inúmeros elementos, incluindo disponibilidade de trabalho, mobilidade, produção, poluição, dentre outros, interferem na ocupação das áreas territoriais, conforme demonstram os modelos desenvolvidos por Forrester (1998) e Meadows (1972) na década de 70 do século passado, que, ainda que de forma mecanicista, permitem compreender as relações entre essas inúmeras variáveis e o dinamismo desse tipo de sistema.

Como integrante desse sistema, o Direito precisa dar conta não apenas da contratualização social, mas também de regrar o planejamento da ocupação territorial e a manutenção dos elementos bióticos e abióticos a fim de assegurar que direitos difusos, como ambiente equilibrado e direito à cidade, estejam conciliados com direitos humanos como acesso à moradia adequada, à água e à infraestrutura.

A relação entre a regulação do território e o planejamento e a gestão territoriais indica a 


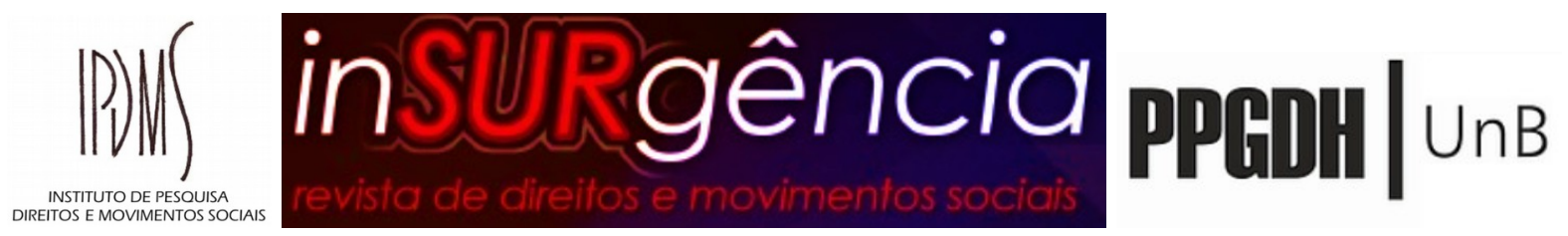

predominância de instrumentos jurídicos voltados preferencialmente à proteção de interesses políticos e financeiros pelo domínio dos lugares, em detrimento da necessária justa distribuição de moradia digna para todos (ROLNIK, 2015; 2019).

Somada à insuficiência de produção de moradia adequada para atender às necessidades sociais brasileiras do presente, a irregularidade fundiária é constituinte das cidades brasileiras, dadas as características de extrema desigualdade social, concentração de renda e alto valor da terra urbana (FERREIRA, 2005).

Nesse sentido, há que se questionar se o conjunto normativo urbano-ambiental é suficiente e coeso quando aplicado aos processos de produção do lugar, em especial quando se dirige aos loteamentos informais ou clandestinos ${ }^{3}$. Ou ainda, se a legislação aplicável está em consonância com a realização dos direitos fundamentais à moradia, à posse, à fruição, ao lazer, ao ambiente equilibrado e à propriedade da população mais pobre.

Ou seja, frente a um contexto em que os assentamentos informais continuam aumentando gradativamente, há que se identificar como a legislação vigente, por vezes, inviabiliza o parcelamento e a ocupação formal do solo, em vista da dificuldade em se atender itens considerados essenciais por norma. Trata-se de uma situação em que a ilegalidade passa a emergir "não pela ação das pessoas, que buscam exercer um direito, mas da ordem jurídica que define a forma adequada de acesso aos direitos” (CAFRUNE, 2016, p. 182).

Como consequência da irregularidade, entra-se em um vicioso círculo de negação de direitos, deixando os assentamentos sem acesso à água tratada ou serviço de esgoto, iluminação pública ou coleta de lixo. Ao invés de prover infraestrutura urbana, a resposta do Estado para a problemática da urbanização em desconformidade com a Lei de Parcelamento do Solo, em especial do sistema de justiça, passa a ser a criminalização das pessoas e coletividades.

Nesse sentido, Reschke et al. (2008) entendem que loteamentos ilegais ou clandestinos, devem ser controlados, e que uma das melhores formas de "repressão" à criação contínua de loteamentos informais seria “o ajuizamento de ação penal pela prática do delito previsto no art. 50 da Lei Federal n 6.799/79”.

O sistema jurídico contribui, assim, para esse cenário perverso em que o direito territorial se constitui de forma a favorecer as elites urbanas, grandes proprietárias de terras.

3 São tratados como clandestinos os loteamentos realizados por loteadores de fato, em desconformidade com a legislação de parcelamento do solo. Não se confundem com as ocupações, em razão de que, em geral, há propriedade registral pelo loteador, mas que não cumprem com as formalidades da Lei 6.766/79. Em ambos os casos, pela definição adotada pela Lei 13.465/2017, tratam-se de “núcleos urbanos informais”. 


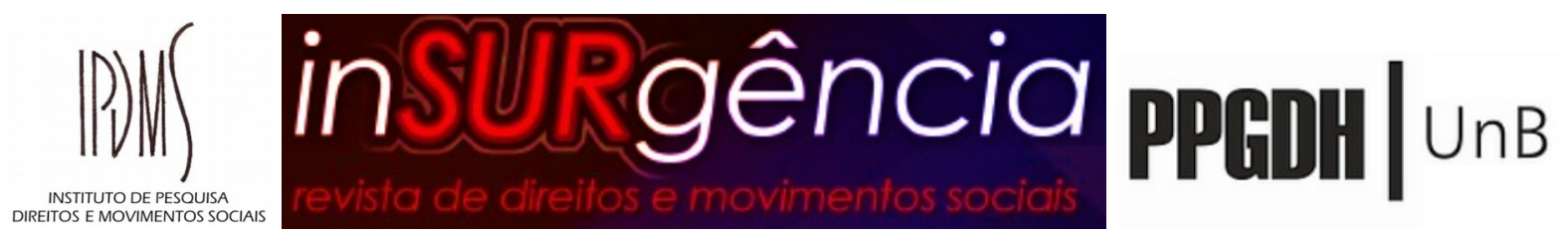

Debates nesse sentido são relevantes para que se vislumbrem caminhos que possam diminuir a distância entre norma e realidade, que só é possível com justiça social, contribuindo para que a sociedade possa ter políticas mais adequadas a cada contexto municipal em sua produção dos lugares de moradia, especialmente no caso de cidades de pequeno porte.

Assim, busca-se trazer à luz a dinâmica dos conflitos e desafios urbano-ambientais que se alternam entre a tentativa de ordenação do território, por parte do Estado, e as "práticas insurgentes” de produção de lugares autoconstruídos (MIRAFTAB, 2016; ROLNIK, 2019), a partir do estudo de caso ${ }^{4}$ do município de São José do Norte.

\section{Os assentamentos informais no Município de São José do Norte (RS)}

Para discutir a problemática da regularização fundiária em cidades de pequeno porte, serão brevemente apresentadas as características do Município de São José do Norte. Após, será descrito o conjunto dos inquéritos civis que, em 2019, tramitavam na Promotoria de Justiça local, acerca dos assentamentos urbanos informais; para analisar alguns aspectos jurídicos das práticas sociais de produção do lugar.

\subsection{Características do Município}

Com formação peninsular, São José do Norte limita-se por terra com o município de Tavares, e nos demais limites, com as águas da Lagoa dos Patos, seu estuário e o Oceano Atlântico, e como se pode identificar na sequência (Figura 1), é composto por ecossistemas delicados e inúmeras áreas de preservação permanente (FREITAS et al., 2015). É um município geograficamente próximo a Rio Grande, uma cidade de médio porte, que provê regionalmente uma série de estruturas de saúde, de trabalho e de educação, mas cuja conexão se dá apenas por transporte aquaviário - o que torna São José do Norte isolado regionalmente.

\footnotetext{
4 Os dados foram coletados no processo de elaboração do trabalho de conclusão de curso, em Direito, da coautora, sob orientação do coautor, intitulado "O Direito do Ordenamento Territorial e as Práticas de Produção do Lugar a Partir da Análise de Inquéritos Civis em São José do Norte/RS” .
} 


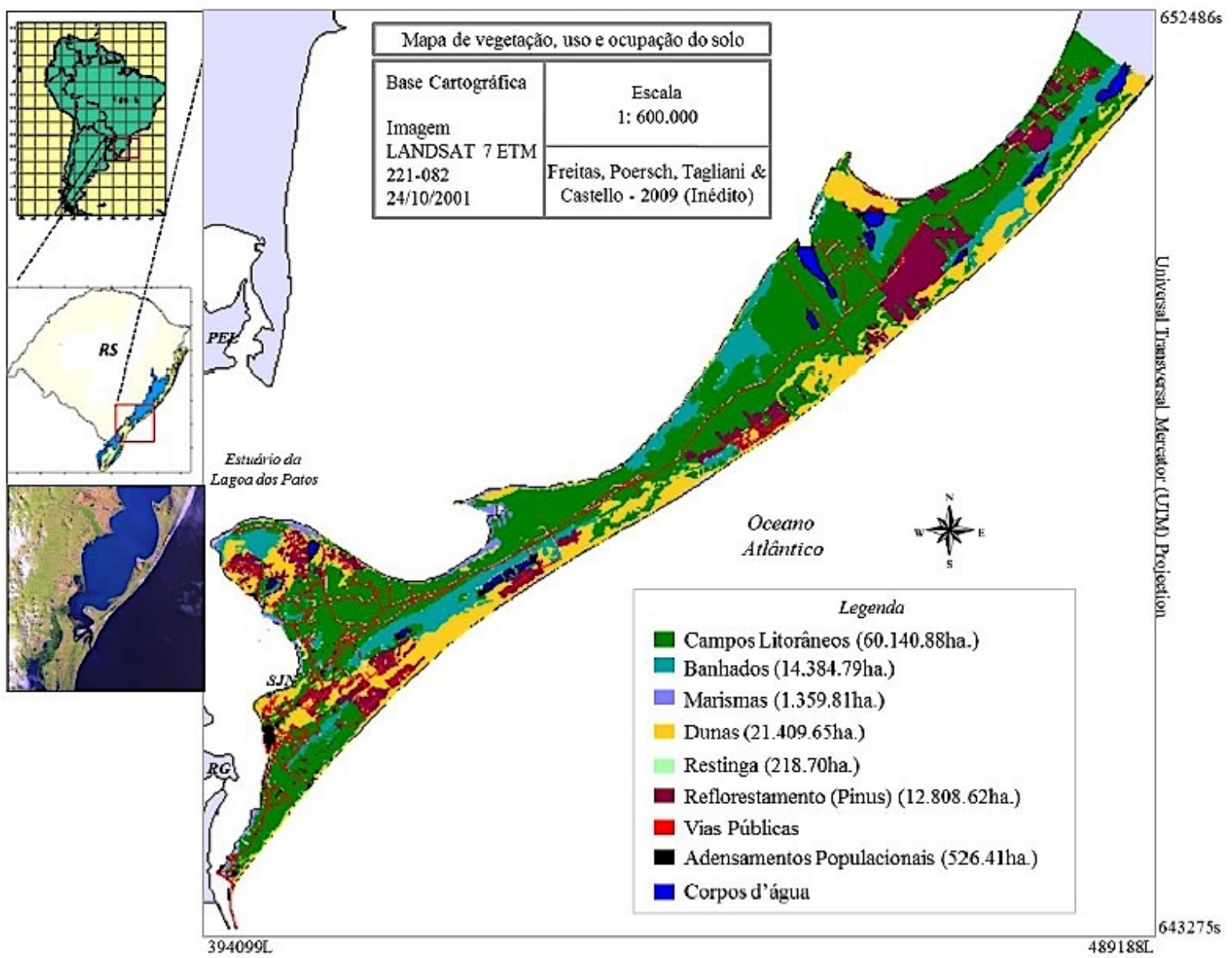

Figura 1 - Mapa de localização do município de São José do Norte, com suas feições ecológicas e geográficas e uso do solo. Fonte: FREITAS, 2015.

Como pode ser observado no mapa apresentado na figura 1, o território do município é predominantemente rural, sendo que os adensamentos populacionais correspondem a uma parcela bem menos expressiva do que as áreas de proteção ambiental. Essa característica acaba se tornando um forte limitante para a expansão dos núcleos urbanos existentes, exigindo um grande investimento em investigações técnicas e proposição de soluções que mitiguem ou compensem impactos ambientais decorrentes de urbanização.

É importante destacar também que São José do Norte possui, além de sua sede administrativa, outros núcleos urbanos esparsos, também irregulares, que se encontram fora do perímetro urbano, e que foram denominados como “Áreas Funcionais” no Plano Diretor do município.

A São José do Norte foi atribuído o título de "Mui Heroica Vila”, por ter sido reduto da resistência portuguesa no período de ocupação Espanhola que tomou Rio Grande de São Pedro por treze anos entre 1763 a 1776, tendo partido desse lugar, via canal do Norte no 


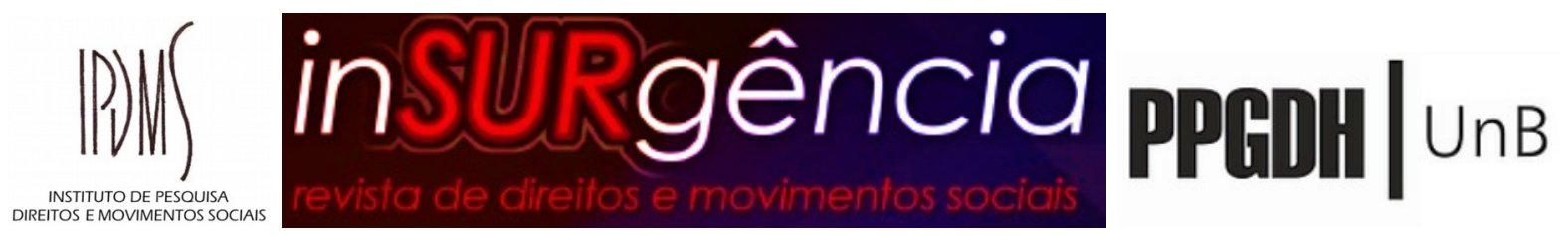

Estuário da Lagoa dos Patos a retomada militar (VEIGA et al., 2017). Esse fato traz reflexos na produção do lugar, pela presença de edificações tombadas e potencial arqueológico.

A população é estimada pelo IBGE (2019) em aproximadamente 27.410 habitantes, com densidade de 22,8 habitantes por quilômetro quadrado e renda média de 3,1 salários mínimos. Chama atenção a estimativa de apenas $20 \%$ da população ser considerada ocupada e $35,7 \%$ ter renda de até meio salário mínimo. Esses dados demonstram a vulnerabilidade social da população no município e, por consequência, a necessidade de políticas habitacionais voltadas à população pobre. Por outro lado, também pode indicar, conforme alegado em um dos procedimentos analisados, que os loteamentos irregulares possam ser uma fonte de renda aos proprietários de terra que não tenham capital para investir em infraestrutura de loteamentos formais.

\subsection{Os assentamentos urbanos informais nos inquéritos civis do Ministério Público de} São José do Norte

Para estudar os aspectos jurídicos que envolvem os assentamentos urbanos informais em uma cidade de pequeno porte, optou-se pela metodologia de estudo de caso a fim de serem conhecidas questões que têm sido discutidas para promover ou impedir a regularização fundiária e o reconhecimento jurídico adequado da cidade existente.

Embora ainda seja um recurso metodológico pouco difundido no campo jurídico, o estudo de casos:

[...] pode trazer resultados de grande utilidade à reflexão sobre as relações estabelecidas entre particulares ou entre estes e o Estado, dinâmicas institucionais, compreensão e aplicabilidade de institutos jurídicos, descrição de um panorama econômico-social com o qual o Direito precisa lidar etc. (GHIRARDI; PALMA; VIANA, 2012, p. 177).

Definido o Município de São José do Norte, iniciou-se a busca de procedimentos de inquérito civil no âmbito da Promotoria de Justiça e identificou-se uma ata de reunião de 2018, em que oito procedimentos de acompanhamento das ações de regularização ou desocupação de áreas vinham sendo cobrados do Município no âmbito da definição de políticas públicas. Esses foram, então, os casos selecionados para estudo, visando compreender seus pontos em comum e a história de cada um deles. Foi solicitado acesso aos procedimentos, que foram disponibilizados para consulta presencial. 


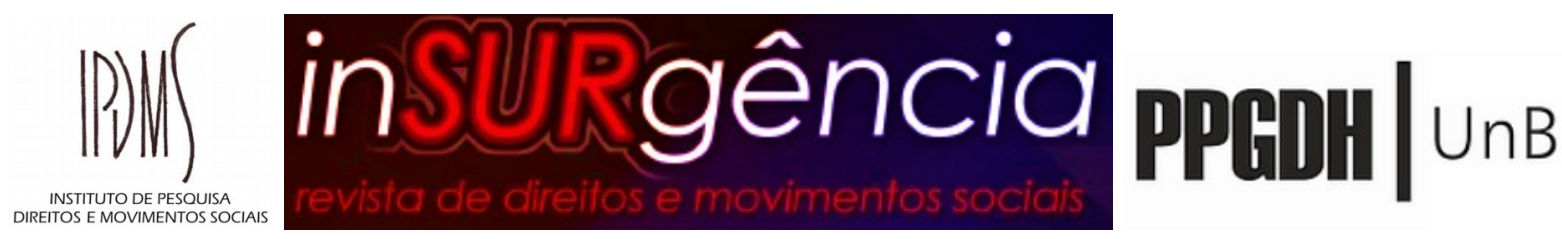

A partir do conteúdo dos inquéritos selecionados, outros procedimentos foram citados ensejando novas consultas que vieram a enriquecer o mosaico que mostra como os processos de produção do lugar em São José do Norte vêm se dando ao longo dos anos em seu conflito diário entre realidade urbana e o direito do ordenamento territorial. Para fins de análise dos inquéritos selecionados, foram criadas categorias que permitissem a comparação da evolução e tratamento dado pelo Ministério Público aos casos. Criou-se uma ficha técnica para cada um deles, incluindo comparação histórica de imagens de satélite obtidas na plataforma Google Earth Pro (2019) a fim de se observar a ocupação do território objeto do inquérito ao longo do tempo, conforme exemplificado na figura 3 a seguir.

3.2.1 IC.008s8.00001/2005 - Loteamento no Comendador Carlos Santos

\begin{tabular}{|c|c|}
\hline Assunto: & Defesa Comunitária - Outras hipóteses ambientais \\
\hline Data: & 11/01/2005 - Registro: $23 / 10 / 2007$ \\
\hline Situação: Tramitando & $\begin{array}{l}\text { Descrição: Objeto: Invasão de Dunas, construções } \\
\text { irregulares em área de preservação permanente. Local: Av. } \\
\text { Getúlio Vargas, São José do Norte, RS. }\end{array}$ \\
\hline Processo-crime: & $\begin{array}{l}\text { 126/2050000247-7 (PROCEDIMENTO ORDINÁRIO- } \\
\text { RECLUSÃO. PROCESSO BALXADO) Crimes Ambientais - Lei } \\
9.605 / 98\end{array}$ \\
\hline $\begin{array}{l}\text { Acompanhamento de políticas } \\
\text { públicas junto ao municipio: }\end{array}$ & 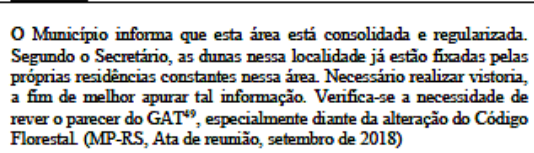 \\
\hline $\begin{array}{l}\text { Termo de Ajustamento de } \\
\text { Conduta (TAC): }\end{array}$ & $\begin{array}{l}\text { 31/03/2008 } \\
\text { CLÁUSULAA PRIMEIRA: No prazo de cento e vinte (120) dias, o } \\
\text { Município de São José do Norte, através da Secretania do Meio } \\
\text { Ambiente, elaborará um Plano de Intervenção no local (manejo dos } \\
\text { lençóis, contenção do avanço e deslocamento das dunas ou remoção das } \\
\text { residências) e enviará cópia ao Ministénio Público, submetendo o Plano, } \\
\text { neste prazo, à aprovaçấo da FEPAM, para licenciamento ambiental, caso } \\
\text { necessánio. }\end{array}$ \\
\hline $\begin{array}{l}\text { Alegações Relevantes dos } \\
\text { Investigados: }\end{array}$ & $\begin{array}{l}\text { Sugiro que a duna seja remanejada e contida com um muro de arrimo, } \\
\text { possibilitando assim, abertura de uma via paralela a avenida Getulio } \\
\text { Vargas, o sentido da via é evitar futuras invasóes e criar um anel viánio. } \\
\text { Com a abertura da via é possivel criar lotes novos voltados para a rua. } \\
\text { Acimado muro sagiro que seja aplicada vegetaçoo rasteira (erama) afim } \\
\text { de evitar deslizamentos de terra (Memorando } \mathrm{N}^{\mathrm{a}} \text { 1553/2013 Secretaria } \\
\text { de Planejamento de SJN). }\end{array}$ \\
\hline Recomendação de remoções: & 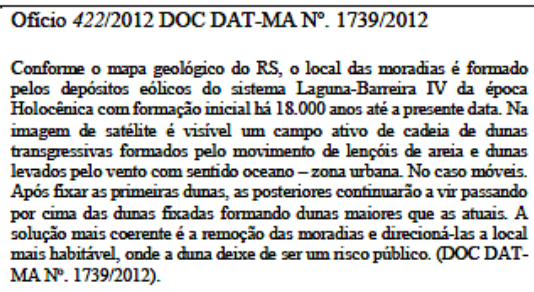 \\
\hline
\end{tabular}
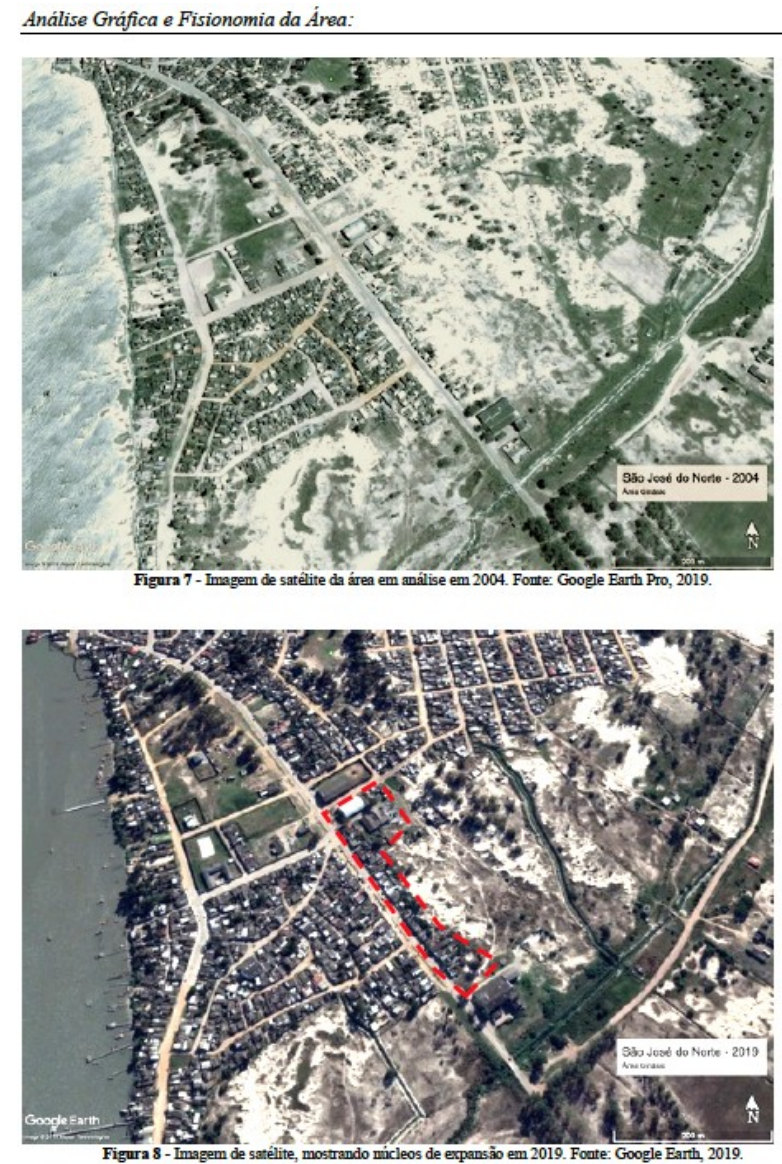

Figura 3 - ficha de análise de caso utilizada como método de estudo.

Dos oito procedimentos que tramitavam na Promotoria de São José do Norte referentes a assentamentos informais ${ }^{5}$, três casos resultaram na assinatura de Termos de Ajustamento de

5 O levantamento foi realizado nos meses de junho e julho de 2019. 


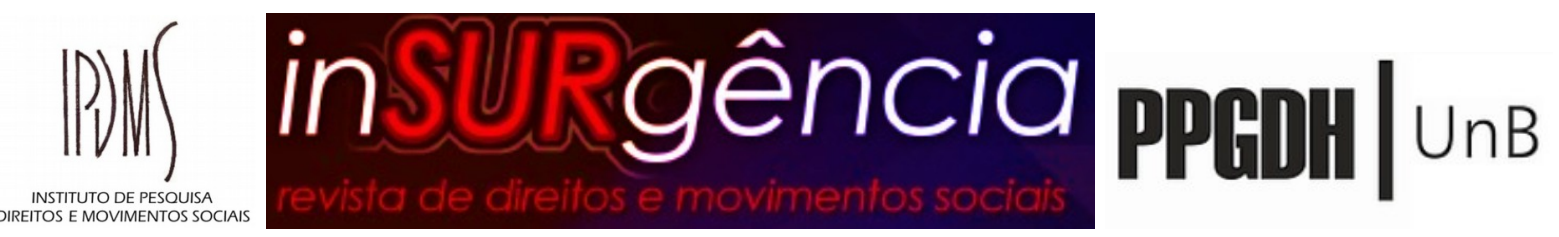

Conduta e seis desdobraram-se em processos criminais na Comarca, como se pode ver na Tabela 1 a seguir.

Tabela 1 - Síntese dos principais pontos identificados nos Inquéritos Civis analisados.

\begin{tabular}{|c|c|c|c|c|c|c|}
\hline & Identificação & Descrição & TAC & $\begin{array}{c}\text { Crim } \\
\text { e }\end{array}$ & $\begin{array}{l}\text { Susp. } \\
\text { Cond }\end{array}$ & $\begin{array}{l}\text { Ind. } \\
\text { Real }\end{array}$ \\
\hline $\begin{array}{l}0 \\
1\end{array}$ & IC.00888.00001/2005 & $\begin{array}{l}\text { OBJETO: INVASÃO DE DUNAS, CONSTRUÇÕES } \\
\text { IRREGULARES EM ÁREA DE PRESERVAÇÃO } \\
\text { PERMANENTE. LOCAL: AV. GETÚLIO VARGAS, } \\
\text { SÃO JOSÉ DO NORTE/RS. }\end{array}$ & $\mathrm{x}$ & $\mathrm{x}$ & $\mathrm{x}$ & $\mathrm{x}$ \\
\hline $\begin{array}{l}0 \\
2\end{array}$ & IC.00888.00014/2006 & $\begin{array}{c}\text { INVESTIGAR A EXISTÊNCIA DE LOTEAMENTOS } \\
\text { CLANDESTINOS PROMOVIDOS POR } \\
\text { "LOTEADOR A6." }\end{array}$ & - & $\mathrm{x}$ & $\mathrm{x}$ & - \\
\hline $\begin{array}{l}0 \\
3\end{array}$ & IC.00888.00014/2010 & $\begin{array}{c}\text { OBJETO: LOTEAMENTO CLANDESTINO NO } \\
\text { CANASTREIRO. LOCAL: SÃO JOSÉ DO } \\
\text { NORTE/RS INVESTIGADO: “LOTEADORES B e } \\
\text { C.” }\end{array}$ & $\mathrm{x}$ & $\mathrm{x}$ & $\mathrm{x}$ & - \\
\hline $\begin{array}{l}0 \\
4\end{array}$ & IC.00888.00013/2010 & $\begin{array}{l}\text { LOTEAMENTO ANA MARIA - LOTEAMENTO } \\
\text { CLANDESTINO EM ÁREA DE PRESERVAÇÃO } \\
\text { PERMANENTE. }\end{array}$ & - & $\mathrm{x}$ & $\mathrm{x}$ & - \\
\hline $\begin{array}{l}0 \\
5\end{array}$ & IC.00888.00024/2013 & $\begin{array}{c}\text { POSSÍVEL DANO AMBIENTAL CAUSADO EM } \\
\text { DECORRÊNCIA DA OCUPAÇÃO CLANDESTINA } \\
\text { EM ÁREAS DE DUNAS NA PERIFERIA DE SÃO } \\
\text { JOSÉ DO NORTE, ESTIMULADA PELO GESTOR } \\
\text { PÚBLICO MUNICIPAL. }\end{array}$ & - & $\mathrm{x}$ & - & $\mathrm{x}$ \\
\hline $\begin{array}{l}0 \\
6\end{array}$ & IC.00888.00012/2014 & $\begin{array}{l}\text { INVESTIGAR OCUPAÇÃO IRREGULAR SOBRE } \\
\text { DUNAS PROMOVIDA POR “LOTEADOR D.” }\end{array}$ & - & - & - & $\mathrm{x}$ \\
\hline $\begin{array}{l}0 \\
7\end{array}$ & IC.00888.00006/2015 & $\begin{array}{l}\text { INVESTIGAR LOTEAMENTO CLANDESTINO NO } \\
\text { BECO DO CANASTREIRO REALIZADO POR } \\
\text { "LOTEADOR E.” }\end{array}$ & - & - & - & - \\
\hline $\begin{array}{l}0 \\
8\end{array}$ & $\begin{array}{c}\text { SIM } \\
01583.000 .315 / 2018\end{array}$ & $\begin{array}{c}\text { PROCEDIMENTO ADMINISTRATIVO DE } \\
\text { ACOMPANHAMENTO DE POLÍTICAS PÚBLICAS. } \\
\text { ASSUNTOS RELACIONADOS À SECRETARIA } \\
\text { MUNICIPAL DE MEIO AMBIENTE E } \\
\text { PLANEJAMENTO. }\end{array}$ & $\mathrm{x}$ & $\mathrm{x}$ & - & - \\
\hline
\end{tabular}

6 Os nomes dos investigados foram substituídos por "Loteador A, B, C..Z”, em proteção as suas identidades, uma vez não serem essas objeto desse estudo, que busca identificar aspectos gerais da urbanização em São José do Norte, ainda que os inquéritos civis sejam públicos. Importante destacar e agradecer o relevante apoio da Promotoria de Justiça de São José do Norte, Ministério Público do Rio Grande do Sul, em disponibilizar o acesso aos autos dos inquéritos, viabilizando o presente trabalho. 


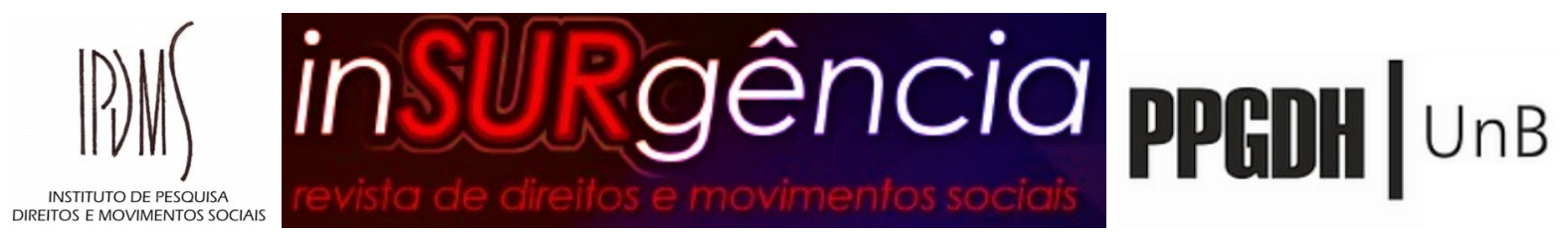

Foi possível entender a história recente do processo de produção dos lugares a partir da análise desses Inquéritos Civis, identificando-se um crescimento habitacional e uma maior expansão urbana a partir de 1994, conforme relata um dos investigados. Identifica-se também, que o Município, ao longo dos anos, apresentou inúmeras justificativas e ações ineficientes que levaram a uma produção urbana à revelia do Poder Público no território. No contexto atual, percebe-se uma movimentação no sentido de regularizar áreas, o que é algo interessante, mas não se identificou nenhuma ação concreta que incentive a produção de áreas formalizadas, mesmo que de iniciativa do poder público, a serem disponibilizadas aos munícipes.

As práticas insurgentes de produção do lugar dão-se pela necessidade de morar: ainda que tal lógica escape às leituras formalistas do Direito, a realidade se impõe: o território é ocupado porque as pessoas vivem nesse território, relacionam-se com ele. Alguns dos parcelamentos foram criados através de abertura de ruas feitas pelo próprio município em terras privadas, viabilizando as ocupações:

\begin{abstract}
No novo local, seriam cedidas áreas de três a seis vezes o tamanho originário, conforme o tipo de edificação, sendo fornecido documento particular de origem e procedência, o qual era necessário para a Administração Municipal efetuar o alinhamento e a localização do terreno, bem como, autorizar a ligação de água tratada e energia elétrica, servindo também de incentivo e compensação para a mudança de local das residências que se encontravam em lugar impróprio, inviabilizando o arruamento do Bairro. Tal ajuste, proporcionou a expansão urbana e a regular observação ao projeto urbanístico traçado para o referido Bairro, bem como, valorizava a propriedade, uma vez que poderiam ser melhor utilizados os terrenos, após efetuada a reestruturação urbanística, tudo com a devida chancela e autorização do Município, o qual arcaria com os custos de maquinário de terraplenagem, extensão de rede de água tratada e energia elétrica, além de possibilitar a ligação por via pública entre o Bairro João Landell e o Bairro Veneza (Relato do Loteador do IC.00888.00014/2006 acerca de ocupação urbana, tida como loteamento irregular, iniciado a partir de 1994 fls. 58-59. Grifo acrescido).
\end{abstract}

Essas práticas remontam à produção do lugar do período colonial, quando a ocupação e expansão urbana se dava pelo arruamento de áreas, o que possibilitava uma morfologia de malha urbana organizada na cidade. Possivelmente pelo seu “isolamento”, o município parece ter trazido essas práticas bem além da entrada em vigência da Lei Federal n. 6.766/1979, que instituiu regras para parcelamento do solo em âmbito nacional, e da Lei Federal n. 6.938/1981, que institui a Política Nacional do Meio Ambiente.

Outro ponto problemático identificado dentro dos inquéritos é a dificuldade de determinação precisa sobre a existência ou não de áreas de preservação permanente em alguns 


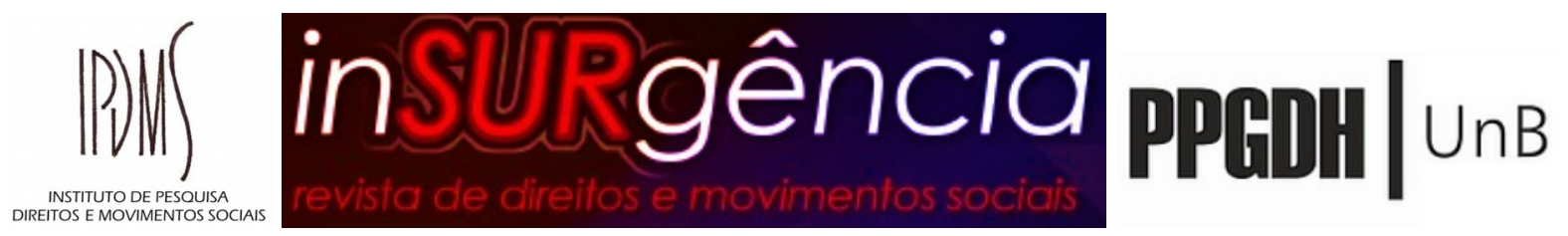

locais, chegando ao ponto de existirem laudos conflitantes e diametralmente opostos dentro dos procedimentos de investigação, alterando a forma de atuação do MP em relação ao caso, em especial acerca da decisão de remover ou não as famílias da área.

Em um deles, após 7 anos de tramitação, com laudos contraditórios acerca da relevância ecológica do ambiente, em um dos quais havia a indicação de que o ambiente de dunas não tinha relevância ambiental frente a outros ambientes úmidos (Furg, fls. 75-76), inclusive com TAC firmado (e não cumprido), e outro, da Unidade de Assessoramento Ambiental/Gabinete de Assessoramento Técnico (GAT) se pronunciando em sentido oposto ao que vinha sendo discutido (fls. 244-246), apontando que o ambiente seria relevante, e que a ação deveria ser no sentido de remover as construções e famílias para ambiente seguro, deixando o ecossistema se regenerar:

[...] o manejo das dunas ou fixação das dunas é uma alternativa paliativa ao ambiente geológico do local, pois a característica do local é de campo de dunas. Após fixar as primeiras dunas, as posteriores continuarão a vir passando por cima das dunas fixadas formando dunas maiores que as atuais. Consequentemente, 0 município será eterno responsável pela fixação das dunas e conforme o "manejo" elaborado pode remodelar e descaracterizar completamente o local de tal forma que possibilite uma futura ampliação do município com a eliminação completa das dunas. (IC.00888.00001/2005. Relatório de Vistoria. Documento DAT-MA n ${ }^{\circ}$ 1739/2012. Unidade de Assessoramento Ambiental. Áreas Protegidas - APP Dunas. Ofício 422/2012)

Atualmente, quinze anos após início do inquérito, a posição da promotoria é pela revisão desse parecer, uma demanda proposta pela Procuradoria do Município (Of. no. 234/2013 - PGM-MSJN) que parte da alegação do Princípio da Razoabilidade frente à recomendação de remoção das famílias, defendendo que a área está consolidada pelas moradias. Até maio de 2020, a referida vistoria solicitada ao órgão de apoio do Ministério Público ainda não teria ocorrido, permanecendo o impasse.

Em relação ao desinteresse de empreendedores privados na produção de loteamentos regulares no município, foram identificadas algumas iniciativas que não vieram a se consolidar

[...] solicitar a concessão de prazo não inferior a 30 (trinta) dias para apresentar novo projeto de intervenção na referida área. Salientamos ser extremamente necessária uma nova análise do projeto anteriormente apresentado, haja vista ser fundamental verificar sua compatibilização com os vários projetos de loteamentos particulares que estão sendo cogitados para a área em foco. (Ofício 006/2012-SMMA. 17 fevereiro de 2012. Grifo adicionado).

Destaca-se que, entre o início e o atual momento do processo, o Município viveu uma expectativa de expansão pautada na existência de um Polo Naval na região, tendo 


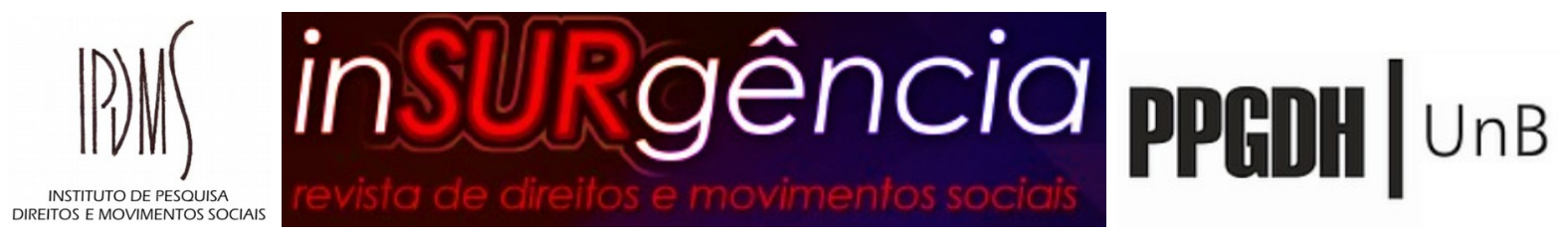

recebido um estaleiro e estruturas hoteleiras que não vieram a se consolidar dentro das expectativas. Em função das crises econômica e política que se sucederam a partir de 2015 e da criminalização de diversos contratos vinculados à empresa Petrobrás, foram sepultados o Polo Naval e todas as expectativas de crescimento socioeconômico e urbano desse município até o momento atual, o que incluiu o abandono de eventuais projetos de loteamento que vinham sendo cogitados.

Outro aspecto que chama a atenção são as dificuldades enfrentadas para identificar quem detém o título de propriedade da área, já que os limites físicos muitas vezes são confusos e mal definidos na documentação dos imóveis. Isso implica que as vezes são inquiridas pessoas supondo-se eventualmente que seriam loteadores clandestinos, mas que podem não possuir relação com a área. Nesse sentido, veja-se esse trecho de declaração constante de Inquérito:

\footnotetext{
Esclarece que dos 120 hectares restaram cerca de 107 hectares e meio, porque 12ha e meio foram vendidos para [...]. Há uma outra parte que foi usucapida pelo Município, outra parte por [...]. Outra parte foi doada para a Mitra Diocesana. Foi cedida uma parte para o DAER, que terceiros tomaram conta quando o DAER foi embora. Foi doada parte para a CORSAN. O depoente vendeu alguns terrenos que completavam alguns quarteirões. Havia muitas invasões no terreno. Por isso, o depoente vendeu alguns terrenos. Quando seu pai ficou doente, o declarante vendeu vários terrenos para custear despesas. Não há loteamento registrado. Há apenas oferta para doação da área ao Município, protocolada. Não sabe o número de lotes negociados. O declarante não ficou com cópia dos recibos que passou aos compradores. O pai do declarante não vendeu nenhum lote, sequer atinaria onde fica a chácara. Hoje, o terreno que sobrou está cercado. A prefeitura arruou. Trata-se do prolongamento da XV de novembro e depois foram feitas as Ruas, 6, 7, 8, 10 e 11 da Cidade Baixa. Da Rua 11 para trás o declarante cercou. Há cerca de 30 anos ocorrem invasões. O terreno corta a Cidade. Hoje, sobram apenas sessenta e poucos hectares. O declarante parou de vender desde 2004, quando começou o movimento para elaboração do Plano Diretor (Termo de Declarações, fl. 17 do procedimento IC.00888.00014/2006. Grifo acrescido).
}

Outra questão que emerge dos depoimentos, a exemplo do anterior, mas que não é o único encontrado, é que as famílias ao precisarem ampliar recursos econômicos por dificuldades financeiras oriundas de desemprego, doença familiar ou dissolução conjugal, utilizam-se da comercialização dos direitos de posse de frações das áreas que possuem como suas, mesmo que nem sempre detendo a propriedade registral do bem. Por outro lado, alguns proprietários não comercializam, mas também não possuem condições financeiras para coibir 


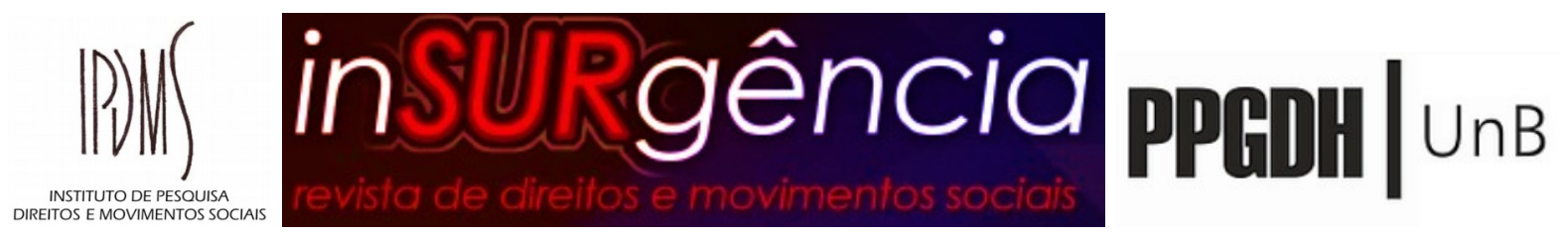

invasões dada a extensão das glebas e sua proximidade com as áreas já urbanizadas, não conseguindo produzir um loteamento regular e vindo a responder pelas ocupações da área:

\begin{abstract}
A Ré [...], igualmente com parcos recursos financeiros, não teve condições de cercar a área, a fim de evitar novas invasões. É humanamente impossível conter o avanço de famílias inteiras provenientes da zona rural do município ou até mesmo dos moradores provenientes de outras regiões da cidade. O executivo, por seu turno, pouco ou nada fez para frear a invasão dos munícipes, tanto na área de propriedade da Ré, quanto em diversas outras regiões da cidade.
\end{abstract}

[...]

A título de exemplo, ainda em 2010, a Ré passou a levantar orçamentos (Doc. Anexo) para realização de projeto de regularização da área. Porém, frente ao elevado custo, o qual esteve entre R \$ 28 mil no ano de 2010 e R\$ 130 mil atualmente, a Ré continua não tendo condições de arcar com todas as despesas (fls. 242-243 do IC).

Diante desse quadro histórico, a Promotoria de Justiça de São José do Norte passou a direcionar os esforços em defender o interesse coletivo, primeiramente com maior enfoque na proteção ambiental, mas cobrando da Municipalidade a apresentação de políticas públicas para todos os casos em análise, incluindo a implantação de infraestrutura adequada e regularização documental das áreas.

Apenas um inquérito mostrou a tentativa do loteador, por cerca de quinze anos, em aprovar projeto urbanístico formal nos órgãos de licenciamento de atuação estadual e municipal, enfrentando diversas alterações normativas durante o processo, incluindo a mudança da esfera estadual de licenciamento ambiental (FEPAM) para a esfera municipal, e a exigência de prospecção interventiva para aferição do potencial arqueológico no local.

\title{
4. Contradições e limites da legislação urbanística e ambiental aplicável a assentamentos informais em cidades de pequeno porte
}

O município de São José do Norte é um exemplo de como os limitantes que aparecem em diferentes contextos se apresentam numa cidade pequena: a dificuldade de aprovação de loteamentos regulares em vista da não disponibilidade de recursos, o desinteresse em investimento em redes de abastecimento, etc. Os loteamentos clandestinos muitas vezes ocupam áreas próximas a áreas de preservação permanente ou estão sobre essas e, via de regra, não possuem sistema adequado de tratamento de esgotos, convivendo lado a lado poços para obtenção de água e fossas sépticas - quando existem. 


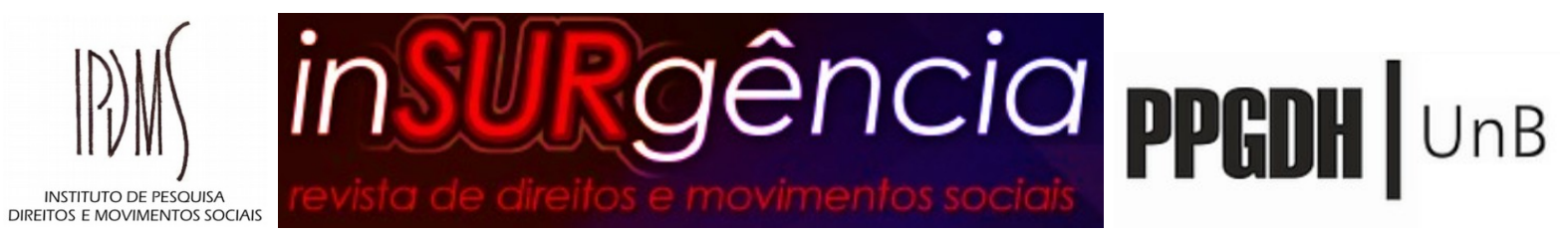

Os depoimentos constantes nos Inquéritos Civis que tramitam na Promotoria de Justiça de São José do Norte, permitem compreender as dinâmicas presentes na produção dos lugares habitacionais informais do município, e identificar eventuais insuficiências do direito na realidade fática desses assentamentos.

No decorrer do estudo, foram identificadas iniciativas por parte do Ministério Público recomendando que: não fossem ligadas novas instalações de energia elétrica nas habitações ${ }^{7 ; 8}$, exigindo a colocação de placas informativas à população de que tais parcelamentos eram irregulares, estando proibida a venda de lotes; além de cobranças de providências da gestão Municipal para que efetivasse políticas públicas para regular a ocupação do território, sob justificativa de viabilizar um morar digno, protegendo o direito ao ambiente ecologicamente equilibrado e à cidade.

No caso de São José do Norte, as ações desse tipo tramitaram por mais de dez anos sem conclusão, ao passo que os assentamentos informais continuam em expansão, indicando que a judicialização não parece ser um caminho que mude a realidade dos municípios se não houver alternativas, a partir de políticas públicas, que viabilizem o direito de morar.

Diante da inexistência de políticas públicas de acesso à moradia, bem como as dificuldades e a falta de interesse de atores do mercado em prover loteamentos regulares em São José do Norte, as ações no intuito de proteger direitos difusos como o ambiental e o urbano acabam conflitando com o direito à moradia e acarretam a criminalização dos assentamentos informais e, por consequência, da população que encontrou caminhos para morar, ainda que insurgentes (MIRAFTAB, 2019; ROLNIK, 2015).

Algumas dificuldades na aplicação do Direito Penal às questões referentes à ocupação do território são evidentes, particularmente por trazerem aspectos bastante técnicos à compreensão jurídica, o que faz com que o enquadramento em determinados tipos penais dependa de forma estreita de perícia técnica de geólogos, biólogos, entre outros profissionais.

Prado (2013) critica a forma como o Direito Penal Ambiental brasileiro está posicionado em leis esparsas, extravagantes ao Código Penal, o que tende a deixar os tipos penais ambientais em um status penal de menor relevância. Em seu entendimento, as leis penais referentes a danos ambientais seriam excessivamente prolixas, casuísticas e tecnicamente imperfeitas, oriundas da visão de especialistas na matéria afetada, mas leigos em

7 A exemplo do relatado no Acórdão da Vigésima Primeira Câmara do Tribunal de Justiça do Rio Grande do Sul APRF No 70072363898 (Nº CNJ: 0000504-06.2017.8.21.7000) 2017/Cível.

8 Conforme demonstrado nos autos analisados e em notícias veiculadas pela imprensa (RBS Rio Grande, 21 mar 2011) e pela página oficial da Prefeitura de SJN (17 out 2018). 


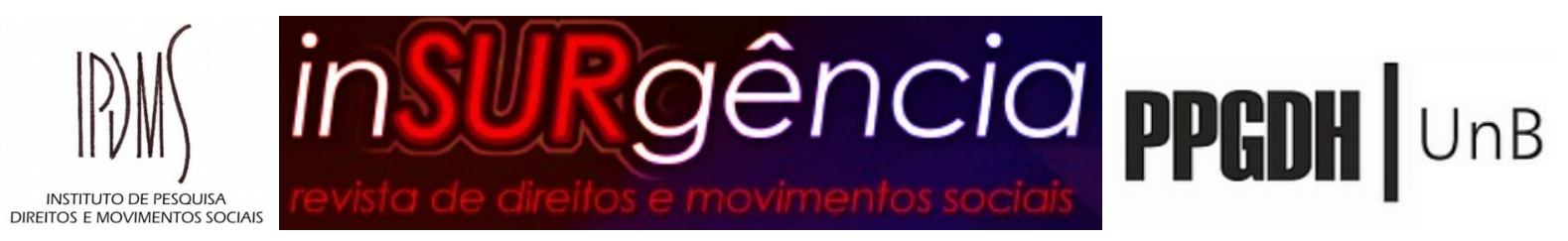

Direito o que dificultaria sua aplicação pela complexidade.

Embora tal argumentação seja atraente, há que se considerar que a norma ambiental não deixa de ser aplicada por ser complexa, mas porque sua incidência reproduz os padrões de seletividade da atuação estatal na tutela de direitos e, especialmente, na realização da pretensão punitiva. Assim, as legislações urbana e ambiental não são compreendidas na medida em que há limitações estruturais à sua implementação. Por outro lado, são instrumentos úteis a serem acionados quando há interesse - como no caso da tutela ambiental para promover remoções de populações urbanas pobres.

Nesse contexto, se percebem inúmeras variáveis que contribuem para a ineficácia da judicialização e criminalização dos assentamentos informais. Dentre elas observa-se, a partir dos dados obtidos, que mesmo estando em curso processos de regularização fundiária no município em estudo, enfrentam-se óbices de difícil transposição, como a recusa de expansão da rede de abastecimento de água tratada por parte da concessionária ${ }^{9}$. Esses fatores indicam que a tutela do direito penal, além de não prevenir e não solucionar problemas relacionados ao direito territorial, complica ainda mais a resolução dos conflitos territoriais urbanos.

Diante desses conflitos, entre criminalizar assentamentos informais e promover acesso à moradia, percebe-se que os instrumentos jurídicos produzem seus efeitos reproduzindo desigualdades, por meio da eficácia normativa seletiva: o direito territorial aplicável, simultaneamente, produz e não produz efeitos.

A realidade fundiária de São José do Norte parece se assemelhar a de inúmeros municípios brasileiros, e mostra as dificuldades de uma cidade de pequeno porte, vinculada às normativas que são generalizadas às cidades de todo país - evidenciando que são poucas as diferenciações que considerem os 5.568 municípios brasileiros (IBGE, 2019), dentro de categorias específicas como porte, economia, cultura, faixa etária ou ocupação e desocupação profissional.

Para lidar com a diversidade das cidades brasileiras, há a exigência de Plano Diretor e a competência municipal para legislar sobre matéria de interesse local. Contudo, para que o Plano Diretor possa induzir o desenvolvimento urbano, é necessário que haja capacidade técnica instalada e utilização correta dos meios jurídicos. Ao realizar o balanço dos Planos Diretores aprovados na primeira década de vigência do Estatuto da Cidade, concluiu-se que há "insuficiente e inadequada demarcação territorial de diretrizes e instrumentos”, o que

9 Ata de reunião MP-RS, setembro de 2018 em IC.00888.00001/2005. 


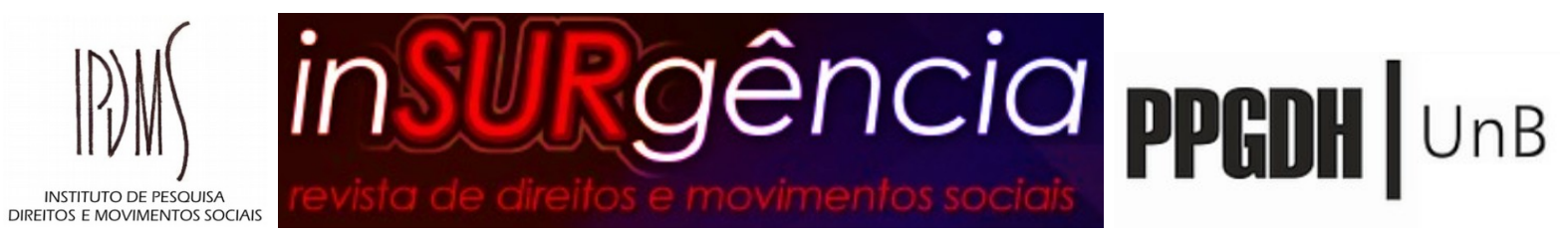

ocorreu, provavelmente, em razão da "baixa capacidade institucional e técnica dos municípios, o que requer uma atenção especial dos governos (...)” (SANTOS JR.; MONTANDON, 2011, p. 34).

A necessidade de que se tenham legislações adequadas a realidades diferentes no âmbito municipal também é uma preocupação de Rodrigues (2008, p. 124), para quem, ao se desconsiderar a extensão territorial dos municípios exclui-se a participação da parcela significativa de moradores no planejamento do território.

Pode-se dizer que avanços, no sentido de flexibilizar a legislação para aproximar as populações de menor renda ao seu direito à moradia, em especial após a publicação do Estatuto da Cidade (Lei 10.257/2001), vem sendo obtidos em Leis como as que instituíram o Programa Minha Casa Minha Vida (Lei 11.977/200910), a REURB (Lei 13.465/2017 ${ }^{11}$ ) e, mais recentemente, a novíssima Lei 13.865/2019 12 que propõe dispensar o documento "habite-se", emitido pelos Municípios para averbação de pequenos imóveis de pessoas de baixa renda.

Algumas dessas leis são controversas por conter diretrizes que viabilizam, de certa forma, a privatização de terras públicas ou a regularização de condomínios de luxo, mas elas também apresentam instrumentos que favorecem a solução para impasses históricos de assentamentos informais que não são tidos como "regularizáveis" e que, portanto, também não recebem investimentos públicos de qualificação urbana, como se identifica no município de São José do Norte.

Alguns pontos dessas normas tiveram influência das históricas lutas dos movimentos pelo direito à moradia, e continua sendo fundamental compreender as dinâmicas de produção dos lugares urbanos e seus reflexos nas normativas do ordenamento territorial. A partir dessa compreensão, é possível que cada vez mais, se possam fazer interpretações legais coerentes com a realidade socioambiental de cada município. E, com o amadurecimento jurídico propiciado pelas decisões judiciais, além de avanços em políticas públicas, que muitas vezes decorrem das cobranças no âmbito das Promotorias de Justiça, seja possível viabilizar de forma articulada os direitos à moradia, à cidade e ao ambiente ecologicamente equilibrado.

10 Dispõe sobre o Programa Minha Casa, Minha Vida - PMCMV e a regularização fundiária de assentamentos localizados em áreas urbanas; [...].

11 Dispõe sobre a regularização fundiária rural e urbana, sobre a liquidação de créditos concedidos aos assentamentos da reforma agrária e sobre a regularização fundiária no âmbito da Amazônia Legal; institui mecanismos para aprimorar a eficiência dos procedimentos de alienação de imóveis da União; altera as Leis $\mathrm{n}^{\text {os. }}[\ldots .$.$] .$

12 Altera a Lei no 6.015, de 31 de dezembro de 1973 (Lei de Registros Públicos), para dispensar o habite-se na averbação de construção residencial urbana unifamiliar de um só pavimento finalizada há mais de 5 (cinco) anos em área ocupada predominantemente por população de baixa renda. 


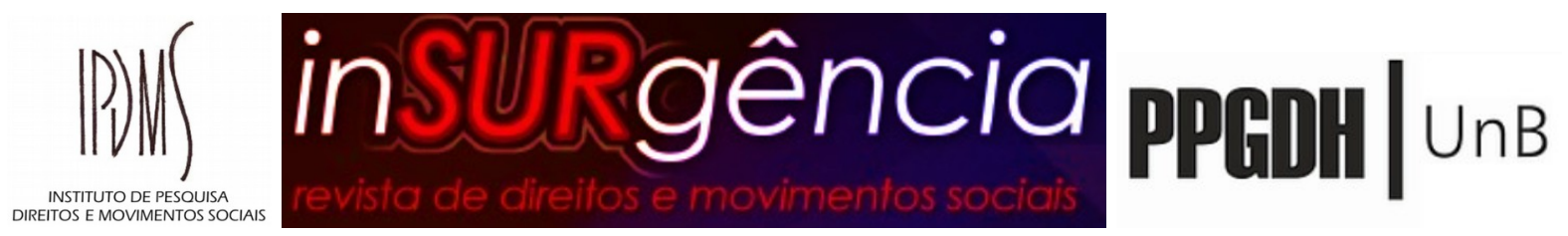

Nesse sentido, como destaca Fernandes (2002, p. 20) dentre as lições de experiências internacionais está “a compreensão da natureza e dinâmica dos processos sociais, econômicos, políticos e jurídicos que produzem a informalidade”, pois essa seria a base para a implementação de programas de regularização fundiária.

Ainda que essa articulação possa parecer utópica, os caminhos para compreensão das dinâmicas dos sistemas urbanos, devem ser constantemente trilhados em vista de sua contínua evolução e adaptação a cada época e a cada contexto. Como aponta Rodrigues (2008, p. 125), “a construção da Utopia do Direito à Cidade depende, fundamentalmente, da ação política da sociedade civil organizada e de estudos que possibilitem construir uma teoria geral dos tempos-espaços urbanos”.

\section{Considerações finais}

Os inquéritos civis analisados delimitam um horizonte de cerca de 15 anos entre o primeiro procedimento de investigação e os atuais acompanhamentos de políticas públicas no âmbito da regularização fundiária. Esses instrumentos, além de terem o propósito de responsabilizar loteadores clandestinos ou irregulares, bem como aqueles que infringem normativas ambientais na ocupação do território, também têm um papel educativo junto aos cidadãos e ao Poder Público. Ademais, tem relevante papel de registrar a história de produção dos lugares, a origem da propriedade e as pressões sociais pelo direito a moradia.

Nesse sentido, o Ministério Público, tanto na esfera Estadual quanto Federal, tem a importante função de ser um catalizador das mudanças propostas pela legislação, em especial no caso dos municípios pequenos. Essa atuação, em defesa da coletividade por vezes, enfrenta conflitos na escolha do caminho legal a adotar, pois o sistema normativo quando se analisam as questões fundiárias, precisa conciliar direitos difusos como o direito ambiental, o direito a cidade, e o direito à moradia ao direito de propriedade e à segurança da posse. O mesmo sistema que protege os direitos humanos pode conflitar com a responsabilidade trazida pelo direito administrativo, onde nada pode ser feito com os recursos públicos sem prévia autorização legal, o que leva à questão acerca de qual interesse público o Estado precisa tutelar de forma prioritária.

Essa questão traz, por vezes, impossibilidades de o Poder Público qualificar 


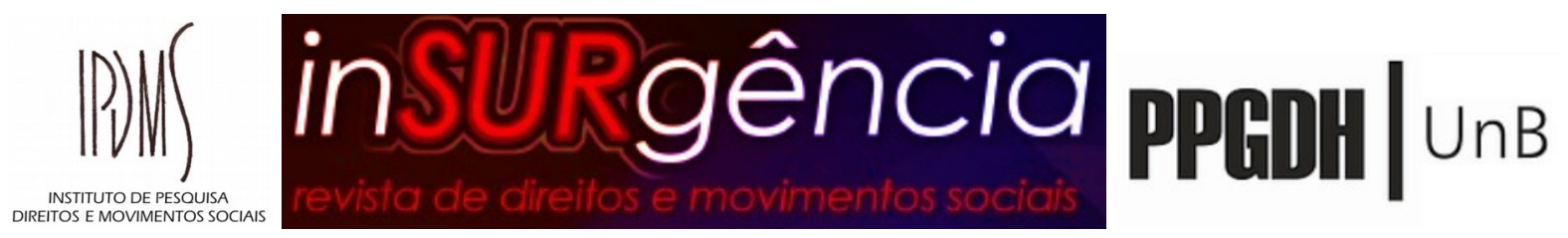

assentamentos informais em vista de configurarem crime previsto na legislação de parcelamento do solo. Por outro lado, esse mesmo poder público, responde pela fiscalização para que não ocorram tais assentamentos, e além de muitas vezes não realizar de forma eficaz seu poder de polícia, tampouco consegue apresentar uma solução adequada de moradia.

Dessa reflexão, pode-se dizer que em São José do Norte, tenta-se a partir de legislação e políticas públicas, solucionar um passivo histórico de irregularidade na produção do lugar que não para de aumentar. O ritmo é inegável, tem sido dado pelo papel fiscalizador e por vezes até conciliador, da Promotoria de Justiça, mas esbarra na limitação de recursos humanos e provavelmente financeiros.

É necessário um planejamento urbano que considere as práticas sociais históricas da cidade real, e, ainda que com excesso de normas que teriam provavelmente maior eficácia se juntas estivessem, como por exemplo, em um “Código de Ordenamento Territorial”, existem instrumentos que podem servir para prevenção da proliferação de assentamentos informais. Mas para tanto, há que se ter em primeiro lugar, vontade política e em segundo, destinação de recursos públicos e políticas de Estado, perenes, ao invés de políticas de Governo, que deem prioridade à moradia com justiça socioambiental.

Dos autos analisados, em especial a partir do registro de reuniões feitas entre integrantes do poder público e o MP, se identificam posições aparentemente equivocadas ao se dar um enfoque excessivo em coibir ocupações. Dentre as sugestões apresentadas pelos presentes estavam o mapeamento de prioridades, ações educativas de orientação da comunidade, limpeza das áreas e sinalização, levantamento fotográfico aéreo com identificação dos limites da orla e levantamento socioeconômico das famílias, a iniciar pela localidade do Barranco.

Ocorre que em não havendo nenhuma política pública para a produção de lotes, ou incentivos públicos para que haja interesse privado em empreender nessas áreas, nada resta à comunidade além da informalidade. Não há alternativas territoriais legalizadas, pois, proprietários de extensas áreas rurais adjacentes ao perímetro urbano, na maioria dos casos, e em especial nos analisados nesse trabalho, não detém recursos, nem perfil empreendedor, nem conhecimento técnico-legal suficientes para promover loteamentos. E os munícipes, não tem outra alternativa diante de sua necessidade de morar em algum lugar, do que ocupar áreas ou adquirir direitos de posse sobre frações de áreas rurais. Ou seja, o foco não deve estar em 


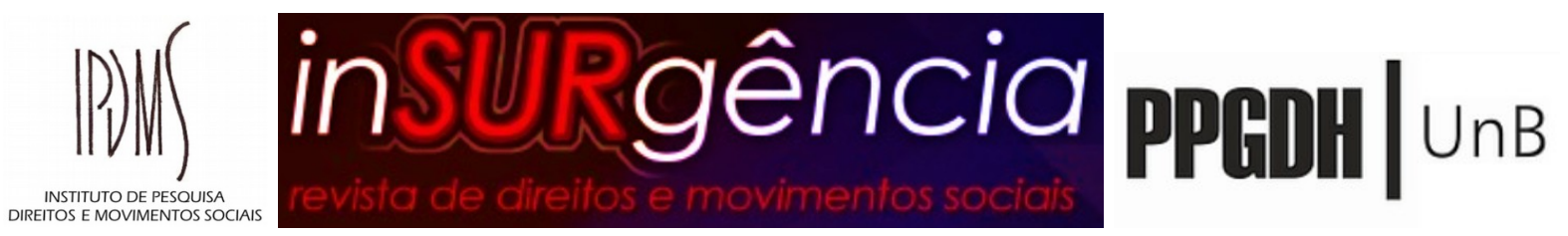

“coibir” ocupações, mas sim em “prover” o acesso da população a áreas adequadas e formalizadas.

Nesse sentido, no que tange ao ordenamento territorial dos assentamentos urbanos em São José do Norte observa-se, a partir da história contada nos inquéritos, que o Município vivencia um esforço bastante grande em “curar” os assentamentos urbanos. É necessário também uma estratégia de “prevenir”, mas só será possível a prevenção a partir de políticas públicas alternativas, que viabilizem o parcelamento do solo com valores financeiramente acessíveis à comunidade de São José do Norte. Quantos municípios mais enfrentam realidades semelhantes ${ }^{13}$ ?

Se para regularizar se permite abrir mão de parâmetros postos na Lei 6.766, por que não rever esses parâmetros conforme o porte e o perfil das comunidades dos municípios?

Enquanto a legislação não refletir a realidade dos municípios haverá práticas insurgentes de produção do lugar. E nesse contexto, essas práticas tem sim legitimidade, pois é o meio que a comunidade encontrou para diminuir a distância entre a precariedade e a dignidade da moradia.

\section{Referências}

BRASIL. Constituição da República Federativa do Brasil. Diário Oficial da União, Brasília, 05 outubro de 1988.

BRASIL. Lei Federal n. ${ }^{\circ}$ 6.766, de 19 de dezembro de 1979. Dispõe sobre o Parcelamento do Solo Urbano e dá outras Providências. Diário Oficial da União, Brasília, 20 de dezembro de 1979.

BRASIL. Lei Federal n. ${ }^{0}$ 6.938, de 31 de agosto de 1981. Dispõe sobre a Política Nacional do Meio Ambiente, seus fins e mecanismos de formulação e aplicação, e dá outras providências. Diário Oficial da União, Brasília, 2 de setembro de 1981.

BRASIL. Lei Federal n. ${ }^{0}$ 10.257, de 10 de julho de 2001. Estatuto da Cidade. Diário Oficial da União, Brasília, 11 julho de 2001.

BRASIL. Lei Federal n. ${ }^{0}$ 11.977, de 7 de julho de 2009. Dispõe sobre o Programa Minha Casa, Minha Vida - PMCMV e a regularização fundiária de assentamentos localizados em

13 Em 2015, o déficit habitacional estimado corresponde a 6,355 milhões de domicílios, dos quais 5,572 milhões, ou 87,7\%, estão localizados nas áreas urbanas e 783 mil unidades encontram-se na área rural [...] O Rio Grande do Sul destaca-se pelo menor percentual de domicílios em déficit habitacional, 5,8\% [...] ainda assim, os números assustam, totalizando um déficit de 239.458 domicílios, sendo 220.953 em zona urbana e 18.505 na área rural (FUNDAÇÃO JOÃO PINHEIRO, 2018) 


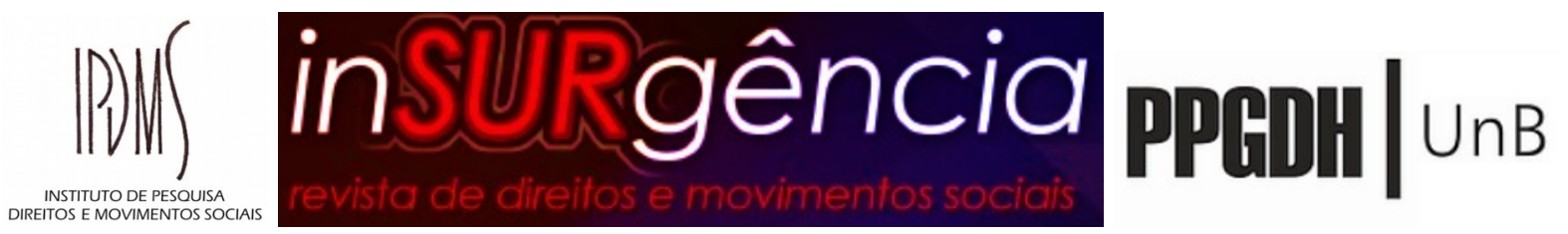

áreas urbanas; altera o Decreto-Lei no 3.365, de 21 de junho de 1941, as Leis nos 4.380, de 21 de agosto de 1964, 6.015, de 31 de dezembro de 1973, 8.036, de 11 de maio de 1990, e 10.257, de 10 de julho de 2001, e a Medida Provisória no 2.197-43, de 24 de agosto de 2001; e dá outras providências. Diário Oficial da União, Brasília, 08 julho de 2009.

BRASIL. Lei Federal n. ${ }^{0}$ 12.651, de 25 de maio de 2012. Código Florestal. Dispõe sobre a proteção da vegetação nativa; altera as Leis $n \cdot{ }^{\text {os }} 6.938$, de 31 de agosto de 1981, 9.393, de 19 de dezembro de 1996, e 11.428, de 22 de dezembro de 2006; revoga as Leis n. ${ }^{\text {os }} 4.771$, de 15 de setembro de 1965, e 7.754, de 14 de abril de 1989, e a Medida Provisória n. ${ }^{\circ}$ 2.166-67, de 24 de agosto de 2001; e dá outras providências. Diário Oficial da União, Brasília, 28 de maio de 2012.

BRASIL. Lei n. ${ }^{0}$ 13.465, de 11 de julho de 2017. Dispõe sobre a regularização fundiária rural e urbana, sobre a liquidação de créditos concedidos aos assentados da reforma agrária e sobre a regularização fundiária no âmbito da Amazônia Legal; institui mecanismos para aprimorar a eficiência dos procedimentos de alienação de imóveis da União; altera as Leis n.$^{\text {os }} 8.629$, de 25 de fevereiro de 1993, 13.001, de 20 de junho de 2014 , 11.952, de 25 de junho de 2009, 13.340, de 28 de setembro de 2016, 8.666, de 21 de junho de 1993, 6.015, de 31 de dezembro de 1973, 12.512, de 14 de outubro de 2011 ,10.406, de 10 de janeiro de 2002 (Código Civil), 13.105, de 16 de março de 2015 (Código de Processo Civil), 11.977, de 7 de julho de 2009, 9.514, de 20 de novembro de 1997, 11.124, de 16 de junho de 2005, 6.766, de 19 de dezembro de 1979, 10.257, de 10 de julho de 2001, 12.651, de 25 de maio de 2012, 13.240, de 30 de dezembro de 2015, 9.636, de 15 de maio de 1998, 8.036, de 11 de maio de 1990, 13.139, de 26 de junho de 2015, 11.483, de 31 de maio de 2007, e a 12.712, de 30 de agosto de 2012, a Medida Provisória n. ${ }^{0} 2.220$, de 4 de setembro de 2001, e os Decretos-Leis n. ${ }^{\circ} 2.398$, de 21 de dezembro de 1987, 1.876, de 15 de julho de 1981, 9.760, de 5 de setembro de 1946, e 3.365, de 21 de junho de 1941; revoga dispositivos da Lei Complementar n. ${ }^{\circ}$ 76, de 6 de julho de 1993, e da Lei n. ${ }^{\circ}$ 13.347, de 10 de outubro de 2016; e dá outras providências. Diário Oficial da União, Brasília, 12 de julho de 2017, (retificado em 6 de setembro de 2017) e texto consolidado publicado em 8 de setembro de 2017.

BRASIL. Lei 13.865, de 8 de agosto de 2019. Altera a Lei $n^{\circ}$ 6.015, de 31 de dezembro de 1973 (Lei de Registros Públicos), para dispensar o habite-se na averbação de construção residencial urbana unifamiliar de um só pavimento finalizada há mais de 5 (cinco) anos em área ocupada predominantemente por população de baixa renda. Diário Oficial da União, Brasília, 9 de agosto de 2019.

BRASIL, Luciano Faria. Por um Direito do Ordenamento Territorial: Elementos Preliminares para um Modelo Integrado de Direito Urbano-Ambiental. In: Revista Magister de Direito Ambiental e Urbanístico no 52 pág. 77-88. Fev-Mar/2014. Ed. Lex Magister. Porto Alegre, 2014.

CAFRUne, Marcelo Eibs. Direito à Moradia e a Copa do Mundo no Brasil. Tese de Doutorado. Programa de Pós Graduação em Direito. Universidade de Brasília. Orientador: José Geraldo de Sousa Junior. Brasília, 2016.

FERNANDES, Edésio. A Produção Socioeconômica, Política e Jurídica da Informalidade Urbana. In: ROLNIK, Raquel et al. Regularização da Terra e da Moradia: o que é e como implementar. Ed. Instuto Pólis. São Paulo, 2002.

FERREIRA, João Sette Whitaker. A cidade para poucos: breve história da propriedade urbana no Brasil. In: Anais do Simpósio "Interfaces das representações urbanas em tempos de 


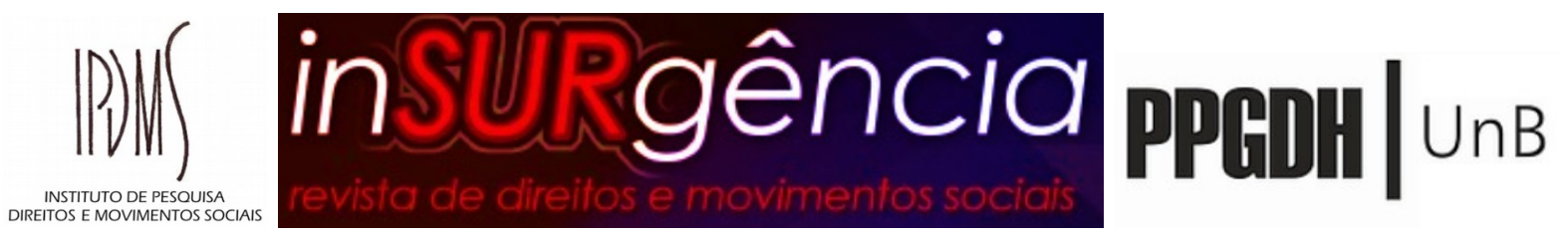

globalização”, UNESP Bauru e SESC Bauru, 21-26 ago. 2005. Disponível em: http://www. usp.br/fau/docentes/depprojeto/j_whitaker/propurbcred.doc. Acesso em 11 set. 2011.

FORRESTER, Jay W. - Urban Dynamics - Portland. Productivity Press, 1969; 1998.

FORRESTER, Jay W. - System Dynamics and the Lessons of 35 Years - A chapter for The Systemic Basis of Policy Making in the 1990s - Massachusetts Institute of Technology Abr. 1991. Disponível em <http://sysdyn.clexchange.org/road-maps/home.html> Acesso em jul. 2005.

FORRESTER, Jay W. - World Dynamics - Portland. Productivity Press. 1973.

FUNDAÇÃO JOÃO PINHEIRO. Estatística e Informações: demografia e indicadores sociais. Déficit Habitacional no Brasil: 2015. Ed. Fundação João Pinheiro. Belo Horizonte, 2018.

FREITAS, Rodrigo Randow; TAGLIANI, Paulo Roberto Armanini; POERSCH, Luís Henrique da Silva. Geoprocessamento aplicado na carcinicultura marinha em São José do Norte, Rio Grande do Sul, Brasil. RGCI, Lisboa , v. 15, n. 2, p. 209-222, jun. 2015 .

Disponível em <http://www.scielo.mec.pt/scielo.php?script=sci_arttext\&pid=S164688722015000200006\&lng=pt\&nrm=iso>. acessos $\quad$ em $26 \quad$ jul. 2019. http://dx.doi.org/10.5894/rgci548.

GHIRARDI; PALMA; VIANA. Posso fazer um trabalho inteiro sobre um caso específico? In: QUEIROZ, Rafael; FEFERBAUM, Marina (coord.). Metodologia jurídica: um roteiro prático para trabalhos de conclusão de curso. São Paulo: Saraiva, 2012. p. 178-190

INSTITUTO BRASILEIRO DE GEOGRAFIA E ESTATÍSTICA - IBGE. Pesquisa Nacional por Amostra de Domicílios. Cidades e Estados. Projeção de 2019. Disponível em https://www.ibge.gov.br/cidades-e-estados/rs/sao-jose-do-norte.html Acesso em 19 de junho de 2020.

MEADOWS, Donella H. et al. Limites do Crescimento: Um relatório para o Projeto do Clube de Roma sobre o Dilema da Humanidade. São Paulo: Perspectiva, 1972.

MIRAFTAB, Faranak. Insurgência, Planejamento e a Perspectiva de um Urbanismo Humano. Conferência de abertura do World Planning Schools Conference 2016. Revista Brasileira de Estudos Urbanos Regionais. V. 18, n.3, p. 363-377, set-dez de 2016. Recife. Disponível em http://rbeur.emnuvens.com.br/rbeur/article/viewFile/5499/4751 acesso em 24 de julho de 2019.

PEREIRA, Tamiris Melo. A Sobreposição Legislativa no Plano Diretor de Goiânia/2007: Meio Ambiente, Urbanismo e Agrariedade. Revista InSURgência. Brasília. Ano 5, v.5, n.1, 2020. IPDMS - Instituto de Pesquisa Direitos e Movimentos Sociais p. 280-321.

RESCHKE, Leila Maria; VARELA, Luciano Saldanha; MORETTO, Simone Santos; SOMENSI, Simone. Loteamentos Irregulares e Clandestinos: Sua Regularização no Município de Porto Alegre. In: Anais do V Congresso Brasileiro de Direito Urbanístico. O Direito Urbanístico nos 20 anos da Constituição Brasileira de 1988 - Balanço e Perspectivas. Org. por Nelson Saule Júnior et al. Ed. Magister. Porto Alegre, 2008. Págs. 30-41.

ROLNIK, Raquel. Contexto político e as práticas insurgentes do planejamento alternativo. FAU USP. Seminário Planejamento Alternativo: alternativas participativas. Instituto Pólis. São Paulo, 19 de fevereiro de 2019. Disponível em: https://www.youtube.com/watch?v=a4bput7upUM Acesso em 24 de julho de 2019.

RODRIGUES, Arlete Moysés. O Espaço Urbano e as Estratégias de Planejamento e Produção 


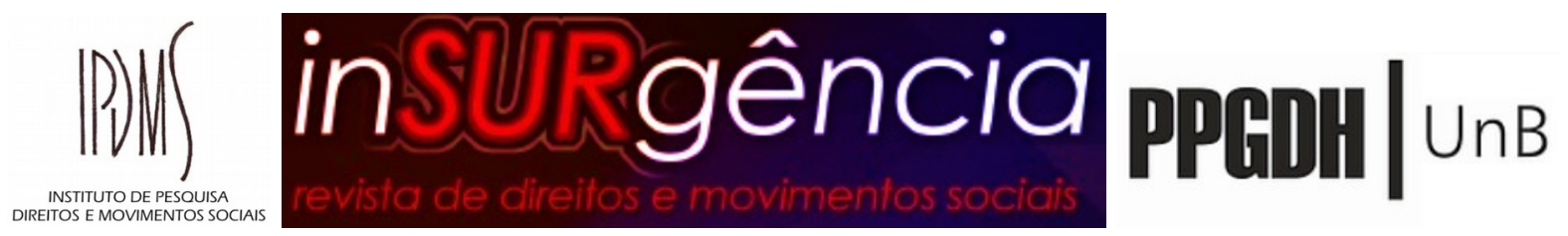

da Cidade. In: PEREIRA, Manoel (Org.). Planejamento Urbano no Brasil: conceitos, diálogos e práticas. Ed. Argos. Chapecó, 2008.

SANTOS JR., Orlando Alves dos; MONTANDON, Daniel Todtmann. Síntese, Desafios e Recomendações. In: SANTOS JR., Orlando Alves dos; MONTANDON, Daniel Todtmann (org.). Os planos diretores municipais pós-estatuto da cidade: balanço crítico e perspectivas. Rio de Janeiro: Letra Capital e Observatório das Metrópoles/IPPUR/UFRJ, 2011. p. 27-56.

PRADO, Luiz Regis. Direito Penal do Ambiente. 5 a . Edição ver. atual. e ampl. Editora Revista dos Tribunais. São Paulo, 2013.

VEIGA, R. C. G.; POUGUET, M.; THIESEN, B. V.; BARCELOS, A. H. F. (Orgs.). Capilla: Capela Nossa Senhora da Conceição. Pensando o restauro, planejando o futuro. Editora da FURG, v. 1. 285p. Rio Grande, 2017.

VEIGA, Rita de Cássia Gnutzmann. O Direito do Ordenamento Territorial e as Práticas de Produção do Lugar a Partir da Análise de Inquéritos Civis em São José do Norte/RS. 2019. 108 f. Monografia (graduação em Direito). Faculdade de Direito. Universidade Federal do Rio Grande, Furg. Rio Grande, 2019.

Submetido em 23/06/2020.

Aprovado em 21/07/2020. 